\section{THE SCOTTISH CONSTITUTIONAL CONVENTION}

\section{James G Kellas}

What is the significance of the Scottish Constitutional Convention? Has it changed Scottish politics in any way, and will it hasten the establishment of a Scottish Parliament?

The Convention, which met in public on seven occasions from $30 \mathrm{March}$ 1989 to 30 November 1990, has had a mixed reception from Scottish politicians, academics and journalists, and only lukewarm support from the Scottish public. As is well known, the Conservatives refused to participate and the SNP withdrew after the initial planning meeting on 27 January 1989. The Greens 'suspended' their participation during the final week of deliberations in November $1990^{(1)}$.

The final Report of the Convention ${ }^{(2)}$ is a short (20-page) brochure which is directed essentially at the general public rather than at legislators or an academic audience. Nevertheless, it can be analysed in academic terms, as wil be attempted here. It is clearly intended to form the basis of legislation, but if the Scotland Act 1978 is any guide, such legislation would be considerably more detailed than the Report. Indeed, that is particularly vague on many matters, such as the electoral system for a Scottish Parliament, the method of revenue-raising, and the "entrenching" of the powers of the Scottish Parliament. The electoral system proposal rejects the 'first-past-the-post' system and seeks one "in which the number of seats for various parties is broadly related to the number of votes cast for them", but it does not specify which system that might be. The revenue-raising proposals are unclear on how the Scottish contribution to the UK Exchequer is to be measured "Entrenchment" of Scottish powers seems to rest ultimately not on any law or Constitution but on making it "practically and politically impossible" for Westminster to overrule or abolish the Scottish Parliament when it sees fit.

The Report is silent on the 'West Lothian Question' (the voting rights of Scottish MPs at Westminster in English matters), the Secretary of State for Scotland, and the number of Scottish MPs. There are of course political as well as constitutional reasons why these topics are skirted round or ignored. They are the favourite attacking-points used by anti-devolutionists, and some of these topics such as the number of Scottish MPs impinge on the strength of the Labour Party, since most of these are presently Labour.

A summary of the Convention's Report in terms of academic analysis would place the scheme somewhere between devolution and federalism. The Claim of Right for Scotland which prefaces the Report asserts the "sovereign right of the Scottish people to determine the form of Government best suited to their needs", and asserts "the right of the Scottish people to secure the implementation of that scheme". This is federal rather than devolutionary language, because it emphasises the bottom-up (Scottish) aspects of legitimate power, rather than its top-down location (Westminster-based). Consistent with federalism too is the talk of "entrenchment" of Scottish powers, and the representation of Scotland in international bodies such as the European Community. There are some quite advanced ingredients such as a Charter of Rights "which would encompass, and improve upon, the European Convention on Human Rights". This implies that within the United Kingdom civil rights in Scotland might be different from those in England, Wales and Northern Ireland. This might be seen as giving Scotland even more independence than a unit in a federal state.

More reminiscent of devolution, however, is the listing of powers which the Scottish Parliament could exercise ("a defined range of powers and responsibilities") while implicitly leaving Westminster with its old unlimited 'sovereignty' intact. Westminster's primary powers over Scotland are however stated to be confined to "defence, foreign affairs, central economic and fiscal responsibilities, and social security policy". While there is a shift in the balance here to Scotland as compared to the Scotland Act 1978, in constitutional terms the status of Scottish Government remains that of devolution from a sovereign Parliament rather than a federal (treaty) arrangement between equal partners, underpinned by a written Constitution of a federal nature. The financia provisions talk of a system of "'assigned revenues", ie revenues assigned to Scotland's Parliament as of right", but that "right" derives from a British Act of Parliament and a British Government's decision, not from a Constitution. Such rights can in theory be easily revoked by the central Parliament, and the limitations on Scottish tax powers ("there should be some range defined so that the variation in income tax up or down cannot be misunderstood as being by a wide margin") are more restrictive than those normally associated with federalism. All in all then, a hybrid between devolution and federalism, with more practical features of the former than of the latter, but with some federal claims at a theoretical level (eg concerning the sovereignty of the Scottish people, and entrenched Scottish powers). However, it must be borne in mind that in academic analysis and real politics federalism and devolution are not always clearly distinguished (for example, Belgium and Spain are not federal countries, but have been partly 'federalised' in the 1980s) ${ }^{(3)}$.

What of academic analysis of the Convention? An 'academic' analysis is one which seeks to avoid a partisan or ideological approach, and instead relates the subject to theoretical concepts and uses a comparative and historical method (looking across countries and across historical periods for guidance). But at the end of the day, even academics cannot avoid parading their prejudices, and I declare my sympathy with the primary aim of the 
Convention, a Scottish Parliament. This does not mean that there is necessarily an 'academic' (scientific) case for such a body, though there might be. Some academics who wrote on the Convention, such as Roger Levy ${ }^{(4)}$ and James Mitchell $^{(5)}$ were critical or even hostile. I was supportive ${ }^{(6)}$, and the wellknown political theorist Bernard Crick was positively ecstatic at the prospect of the Convention provoking fundamental constitutional reforms throughout the United Kingdom ${ }^{(7)}$.

An academic study of the Convention would look at the degree of support which it was accorded generally. Here the media plays a crucial part in linking political elites with the mass public. Journalists tended to follow the proprietorial/editorial line of their papers, although some like Neal Ascherson in the Independent on Sunday were veteran devolutionists in the indifferent London environment. The Scotsman and Glasgow Herald were supportive, but the Sunday Times Scotland was opposed. Other papers in Scotland, especially the tabloids, paid little attention to the Convention. Broadcasting gave good coverage at first, but eventually made only brief reports in news and current affairs programmes.

The public at large was divided fairly equally into those who had heard of the Convention and those who had not, but polls continued to show around three-quarters in favour of some form of Scottish Parliament (including independence). It was somewhat worrying for the Convention, however, that by May 1991, a poll ${ }^{(8)}$ showed independence to be a more popular option (supported by $37 \%$ ) than devolution within the United Kingdom, the Convention's proposal (supported by 33\%). Moreover, if a Scottish Assembly were to lead to Scotland having higher taxes than England, respondents split equally (at $43 \%$ ) for and against having such an Assembly. To that extent then, the Scottish people were divided on the conclusions of the Convention, although these might not necessarily imply higher taxes.

In Scottish history Conventions come and go, and for some observers nothing much seems to change. There is still no Scottish Parliament, let alone Scottish independence, and not all that much hope for one either if the Conservatives remain in government. Even Labour cannot be trusted to deliver, according to some, and the Liberal Democrats are perennially powerless. Moreover, some of these critics see the Convention's proposals as fatally flawed anyway. No sensible person, according to them, would want the Convention's brand of devolution. This is the view of the Conservative establishment, the CBI and Chambers of Commerce, big business, and some Conservative Churchmen in the Church of Scotland (the General Assembly in May 1991 saw an unsuccessful attempt to divest the Kirk of its support for the Convention).

Is there an 'objective' political science way to look at these questions, or must we always resort to partisan or sectional mud-slinging? In another article, I tried to examine the constitutional options for Scotland from the perspective of political science, that is to say from a theoretical point of view, using comparative and historical studies ${ }^{(9)}$. Here, I shall take a similar approach to the Convention. I have indicated that other academics have strong views about the Convention, and that therefore no academic consensus is likely to emerge on the subject, at least on the pros and cons of the Convention's proposals. However, perhaps the nature of the disagreements could be put into an academic context, and the reader might then be able to consider what mode of interpretation is involved.

\section{Change and continuity in Scottish politics: the devolution ratchet}

While there have been 'Conventions' before in Scottish history (Mitchell discusses those in 1924, 1926, 1927, 1947, 1948, 1949), there has never been a Convention with such a wide membership, and with such an extended series of meetings. Moreover, quite an elaborate organisation was set up, underpinned by the Convention of Scottish Local Authorities, which also provided some of the funding. Thus history does not just 'repeat itself', and a historical framework must take account of change as well as continuity (Levy sees this clearly, though he disapproves of the direction of the change).

Most significant was the presence at the meetings of a large number of MPs, local councillors and delegates of the Churches, STUC, and so forth. From a purely political point of view, the participation or support of leading politicians in the Labour Party and the Liberal Democrats gave added status to the Convention proceedings. It also meant that the main Opposition parties were effectively committed to the Convention's Report, and they promised to legislate on it if returned to power. No previous Convention had this sort of support. It is true that these promises will have to be put to the test. But the ratchet of progress towards devolution has been turned at least one notch by the Convention.

The boycott of the SNP and the Conservative Party clearly dented the devolution consensus, but it is not clear what effect this has had. What these parties feared above all was being committed to policies they did not wish to support by being outvoted on the Convention. This applied also to the Liberal Democrats and Greens, who nevertheless participated. While the final Report confirmed the worst fears of the non-participating parties (and at the end also of the participating Greens), the agreement between Labour and the Democrats was significant in view of the possibility that a future Labour Government might be dependent on Democrat votes in a 'hung Parliament'. So two future possible election results (overall Labour majority, and LabourDemocrat majority) were catered for by the Convention's deliberations. The Leader of the Opposition, Neil Kinnock, declared that a Labour Government would legislate on devolution during its first year of office, and another Labour Shadow Government spokesman Roy Hattersley has backed the Convention scheme. No party leaders had ever before made such a commitment with regard to a Convention scheme. It may be argued that 
Labour and the Democrats would have introduced devolution anyway, without the Convention. But as we shall see, the Convention changed the nature of the devolution proposals, and heightened its priority in the Opposition parties" programmes.

The absence of the SNP and Conservatives probably makes no difference to the strength of the Convention's influence. The SNP has not increased its vote by non-participation, if anything the reverse. It is likely that when the next devolution Bill is introduced, the SNP will split as over the Scotland Act, but with the same tendency to settle for "half a loaf rather than no bread". The Conservatives may also split, for their devolutionists are now re-asserting themselves under John Major's benign regime. In any case, they would be out of power should the legislation be introduced.

\section{How the Convention changed the devolution proposals}

Until 1989, when the Convention commenced, devolution proposals were to be found in the programmes of the Labour and Liberal/SDP Alliance parties. There were obvious differences between these programmes, notably in the federalist nature of the Libcral proposals, and in the more devolutionist approach of the Labour Party. By the time the Convention reported at the end of November 1990, the Labour proposals had merged with those of the Liberals. There was even a commitment to change the devolved electoral system in the direction of proportional representation, something the Labour Party had always resisted, and still resists for Westminster. A new system of 'assigned revenues' was accepted eventually by the Convention. This was traditional Liberal policy, and was different from the Labour 'block grant' proposals of 1978 , although an element of block grant remains in the form of an equalisation payment from the British Parliament, to be based on needs in Scotland. This would be negotiated with the Treasury. Academic assessments of fiscal federalism and devolutionary finance stress the multiplicity of arrangements in different systems, and the ultimate importance of political will rather than economic factors ${ }^{(10)}$.

These proposals show that the Convention has again turned the ratchet of devolution one or two notches higher where it mattered - in the programme of a prospective British government (this is recognised by critics such as Levy and Mitchell, who nevertheless dismiss the Convention's proposals). The reason for this development is entirely due to the Convention process. The Labour Party needed to retain the cooperation of the Democrats if it was to be a Convention rather than the Labour Party Conference under another name. A the same time, the Democrats needed Labour if the Convention was to be a credible exercise in constitution-making. Curiously, the Democrats seem to have taken most of the initiatives and to have prevailed in argument on nearly every occasion. Similar inputs came from the women's movement (representatives in the Labour Party and STUC, and the Scottish Convention of Women) and the Greens. So the tail in effect wagged the dog. Political scientists call this the "minimum winning coalition', although here it is a moral coalition, since Labour already had a majority in the Convention. Of course, after a general election the minimum winning coalition in the House of Commons would consist of seats only, and might be Labour alone. Yet it will be difficult for Labour to shake off its Convention commitments, assuming that it would wish to do so, which it may not given the strength of Scottish Labour backbench pressure in the 1990s.

\section{The Convention's Proposals: Do they make political sense?}

The Convention's Report to the Scottish People was the result of eighteen months" negotiation between the delegates who comprised the Executive Committee (the plenum merely endorsed without vote). The result was obviously a political compromise between parties and organisations. Does that matter in politics? Most constitutions have been designed in this way, the classic case being the American Constitution, cobbled together over four months in the Philadelphia Convention in 1787. It still exists. Ratification in Britain will have to be in the UK Parliament, through an Act passed by a majority present and voting. No referendum is planned this time. In the US, ratification was to be by nine out of thirteen states. In the event, the US started with eleven states in 1789 , and the two others joined soon after.

If there is no Labour Government, then ratification of the Convention's proposals in legislation becomes virtually impossible (it seems unlikely that the Democrats would ally with the Conservatives to obtain devolution, but it is remotely possible). The Convention's fall-back strategy if it cannot get legislation through Westminster remains unclear. Appeals to the Scottish people through a referendum are on the cards, but this is no 'revolutionary" Convention, on the French or American models. As Mitchell notes, a unilateral declaration of devolution is a "constitutional absurdity'(11). But wait a minute. The Convention's Report is itself a unilateral declaration of devolution, and it has already captured the (British) Labour Party and its leaders. So British politics is responsive to unilateral declarations of this kind, even if the British Constitution is not.

What of The Claim of Right for Scotland, with its declaration of the sovereignty of the Scottish people? Is this an absurdity too? To Levy it is dangerous nationalism, yet it has been subscribed to by the law-abiding signatories of the Convention (including Privy Counsellors Sir David Steel and John Smith, and the Shadow Secretary of State for Scotland, Donald Dewar). Political scientists (unlike philosophers) tend to take claims of sovereignty with a pinch of salt, and work out the implications from practice not theory. Thus the declarations of 'sovereignty' by the Ukraine and other Republics in the USSR, and by the 'sovereign states' in the US, do not neccssarily mean the same thing, or indeed anything of a specific nature. What the Convention means by it has been well noted by the SNP. It does not mean independence for Scotland, because the Convention is wedded to devolution within the UK. 
What it seems to mean is a quasi-federal assertion of 'independence within a sphere' on a coordinate (not subordinate) basis with the British Parliament. Does that make political sense? It probably does, at least as much as the Treaty of Union 1707 (with its two Established Churches, two legal systems, etc), and the Government of Ireland Act 1920 and its successors (the despised 'unilateral devolution' rejected by the Conservatives for Scotland, but pressed by them on Northern Ireland). Britain and British politics seems to be capable of almost any twist in territorial constitutional arrangements.

Yet there are many problems of a technical nature still to be addressed if Parliament comes to legislate on the Convention's proposals. The most tedious of these is the 'West Lothian Question' (can't we leave that one alone?), followed by the existence or not of the Scottish Secretary (who cares, except perhaps the potential office-holder?). More important (but not much more) is the question of the number of Scottish MPs in the House of Commons; quite important is the revenue-raising system for a Scottish Parliament; and crucial may be the nature of the electoral system (without PR, Scotland looks at the moment like a one-party state dominated by the central belt). This is particularly important for the Democrats, whose continued support is valued by the Labour leadership.

Political scientists (when they are speaking as such and not as partisans) have no clear answers to any of these questions. They tend to let politicians or the people decide for themselves in each country, and then assess 'success' or 'failure' in terms of stability, efficiency, responsiveness, and so on. In other words, all these 'problems' are essentially political rather than 'scientific' questions, matters of preference and will. The analysis of these is not easy, because things keep shifting, and both elite and mass inputs are involved. Reversals of party policies are notorious in devolution, and it might not be too surprising to find the Conservatives espousing federalism or even Scottish independence (there is already some evidence of this, with Conservative Scottish Office minister Allan Stewart saying that he would give independence his second preference after the status quo $)^{(2)}$. Malcolm Rifkind (Secretary of State for Scotland, 1986-1990) has always proclaimed his support for federalism (when the English are ready for it).

It is possible to attempt political science theory here, using comparisons with other countries facing similar problems, and looking at how in history state structures have changed, especially in Europe. All the evidence points to devolution or federalism as a contemporary 'stage' in the development of the state, but in a bewildering variety of forms (try Spain for a start). So it looks as if devolution is coming to Scotland, and sooner rather than later, if it is accepted that decentralisation of power is a general feature of contemporary politics in Europe.

Where does this leave the Convention's proposals? They are probably more 'advanced' than most devolution systems, for reasons which relate back to the Convention's process of decision-making. The inclusion of the principle of equal representation of men and women can be related to the input of the women's movement, which is particularly strong in the Labour and Democrat parties. Then, the panoply of legalisms regarding 'entrenched powers', a Bill of Rights, and Scottish representation in the European Community seems to have come from the lawyers in the Liberal Democrat delegation. The Churchmen on the Executive (curiously important, though not mainstream parish ministers, rather Canon Kenyon Wright of Action of Churches Together in Scotland and Rev Norman Shanks - a Glasgow University lecturer) topped up the whole thing with morality, sentiment and historic memory. The eminence grise of the Claim of Right was reportedly James (Jim) Ross, the retired Scottish Office Under Secretary, formerly in charge of the illfated Scotland Act, who knew well its deficiencies (he knew even better the deficiencies of Scottish government). His legacy carried over into the Convention's deliberations, though he does not appear to have been an active participant. He gave an unusually professional flavour, along with the Liberal Democrat lawyers, to an otherwise amateur exercise. Economists such as David Heald were important influences on the revenue side. All in all, an impressive array of the 'great and good' within the Liberal-Labour-nationalist establishment (not of course SNP Nationalists, except for Isobel Lindsay, who effectively left the SNP over the Convention), underpinned by the hard and practical men (and some women) of the Labour Party, local authorities (mainly the same people), the STUC, and so on.

The final meeting of the Convention to present its Report to the Scottish People on 30 November 1990, included a 'Procession of Civic Heads of Scottish Local Authorities' in full regalia in the new Glasgow Royal (yes, Royal) Concert Hall, and 'A Celebration' by various singers, poets, writers, and musicians. All were in exuberant (if sometimes melancholic) form. It looked like a nation being reborn, but soon the doubts returned. Where was the popular will to force it through? What if Labour was not in power to do it? Political scientists, bruised by their failure to predict nationalist revolutions in Spain, the Soviet Union, Yugoslavia, Czechoslovakia, or anywhere, like everyone else, must 'wait and see'.

\section{James G Kellas, Department of Politics, University of Glasgow.}

\section{August 1991}

\section{References}

1. For the early history of the Convention, and the attitude of the SNP at the planning meeting, see I Macwhirter, "After Doomsday... The Convention and Scotland's constitutional crisis", in A Brown and D McCrone (eds.), The Scottish Government Yearbook 1990, pp.21-34.

2. Toward's Scotland's Parliament. A Report to the Scottish People by the Scottish Constitutional Convention (The Scottish Constitutional Convention, Rosebery House, 9 Haymarket Terrace, Edinburgh EH12 5XZ, November 1990). See pp.84-97 below. 


\section{Scottish Government Yearbook 1992}

3. A recent work emanating from the Centre for Federal Studies at the University of Leicester, Murray Forsyth (ed.), Federalism and Nationalism, Leicester University Press, 1989, includes chapters on Spain, Belgium and Corsica, although none of these are nominally federal.

4. R Levy, "Eleventh-hour questions as Convention prepares to deliver its findings." Glasgow Herald, 30 November 1990 . See also his Scottish Nationalism at the Crossroads, Scottish Academic Press, Edinburgh 1990.

5. James Mitchell, Constitutional Conventions and the Scottish National Movement: Origins, Agendas and Outcomes, Strathclyde Papers on Government and Politics, no. 78 (University of Strathclyde Department of Government, Glasgow 1991).

6. James G Kellas, "Prospects for a New Scottish Political System", Parliamentary Affairs, vol. 42, no.4 (October 1989), pp.519-32, and "Constitutional Options for Scotland", ibid., vol.43, no.4 (October 1990), pp.426-34.

7. Bernard Crick, "The growing threat from Scotland", Observer, 4 March 1990.

8. Scotsman, 9 May 1991 . The figures are $33 \%$ for a "tax-raising Assembly"; $24 \%$ for "an independent Scotland which is part of the EC"; 13\% for "an independent Scotland outside the EC"; $28 \%$ for "the status quo"; $2 \%$ don't know/did not answer

9. Parliamentary Affairs, op cit., October 1990.

10. See for example David Heald, "Financing an Assembly", in David McCrone (ed.), Financing Home Rule (Unit for the Study of Government in Scotland at Edinburgh University 1990), p.38.

11. op cit, $\mathrm{p} 14$.

12. "Stewart moves to head off Tory devolution support", Scotsman, 29 April 1991. 